\title{
US energy moves signal budget fights ahead
}

Washington. Attempts by Republican members of the US Congress to place an upper limit on research spending at the Department of Energy (DoE) have given a warning of what the research community can expect if - as is widely predicted - the Republican party makes substantial gains in November's congressional elections.

Representative Robert Walker (Republican, Pennsylvania) has been leading an effort to limit non-defence research and environmental restoration work at the $\mathrm{DoE}$ at this year's level of $\$ 4.29$ billion until 1998. This move would eliminate any increases for inflation, and force all new spending - such as that proposed for new fusion and high-energy physics facilities - to be taken out of other work covered by the limit.

Walker's bid to limit DoE spending has taken the form of an amendment to the Hydrogen, Fusion and High Energy and Nuclear Physics Authorization Act. The move has angered many Democrats, who point out that overall federal spending is already capped by existing law.

But Walker and his conservative backers believe that such an overall limit still encourages Congress to spend money in favoured areas - such as scientific research - without considering where the money will come from.

The House of Representatives was this week due to debate a version of the bill that already included a cap of $\$ 3$ billion on research into energy supply (although some of the bill's supporters assumed this would be removed from the bill in conference with the Senate).

Walker's amendment extends the scope of the cap to cover high-energy and nuclear physics as well; if adopted, the result would be that the proposed expansion in these fields would have to be offset elsewhere.

Sherwood Boehlert (Republican, New York) was due to offer a compromise amendment raising the cap by $\$ 50$ million for three years. The extra money would be used to fund the high-energy physics work proposed earlier this year by a panel led by Sidney Drell of the Stanford Linear Accelerator Center (see Nature 369, 266; 1994).

The authorization bill does not directly set research budgets - that is done each year by appropriations committees. But observers of the science policy scene in Washington say that the importance of Walker's amendment is as a pointer to the future for research funding.

Research scientists who have spent recent years complaining about budgets that have risen only at close to the rate of inflation may now see budgets frozen in cash terms, and policed by a more fiscally conservative Congress.

The Republicans are unlikely to win control of the House of Representatives in No-

vember, when all its members and one-third of senators are up for re-election. But they are likely to return as a larger and more conservative group, easily capable of winning a majority in alliance with conserva-

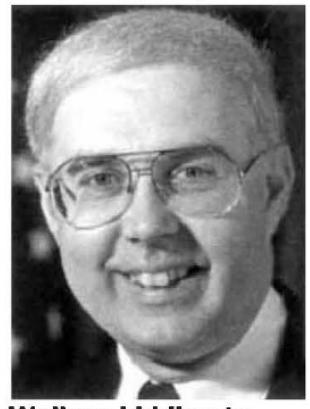

Walker: bidding to limit DoE spending.

support for their work.

Once the House has dealt with the authorization bill, its fate will rest with Senator Bennett Johnston (Democrat, Louisiana), who steered a bill authorizing fusion alone through the Senate last year and must now decide if he wants to proceed with the

\section{House's wider bill.}

Johnston was originally keen on a fusion bill to ensure that the United States had a coherent plan for fusion, and prevent it from 'wasting' $\$ 650$ million on the planned Tokamak Physics Experiment (TPX) at Princeton Plasma Physics Laboratory, New Jersey (see Nature 367, 669; 1994). He has not so far revealed his position on the House of Representatives' proposals for highenergy physics, which support Drell's call for US participation in Europe's Large Hadron Collider (LHC).

If Johnston is enthusiastic, a bill could be passed before the present Congress holds its final sitting in October. That would be good news for physicists (especially if the spending caps are knocked out), as it would offer some protection to fusion and high-energy physics programmes in what are expected to be difficult years ahead by formally endorsing them in law. It would also lend some purpose to the long, hot August sitting that has been forced upon Congress by the Clinton administration's efforts at health-care reform.

Colin Macilwain

\section{Biosphere 2 wins growing approval}

Washington. Biosphere 2, the ecological laboratory built in Arizona by Ed Bass, a Texan billionaire, has replaced its scientific director and is planning a new scientific programme in partnership with Columbia University, New York.

Officials say the changes mark a new beginning for the much-criticized laboratory, which includes the world's largest hermetically sealed greenhouse. Biosphere 2 has asked a number of prominent scientists to produce reports by the end of the year on its research potential in a dozen different scientific disciplines, ranging from ecological modelling to nutrition.

The scientific programme will be overseen by a committee of four members: Michael Crow, vice-provost of Columbia; Wallace Broecker, of Columbia's LamontDoherty Earth Observatory; Bruno Marino, Biosphere's new scientific director; and Stephen Bannon, acting chief executive of the private company that runs Biosphere 2 for Bass.

The committee will be given advice by a panel of scientists chaired by Michael McElroy, chairman of the Earth sciences department at Harvard University.

Marino was also previously a member of Harvard's Earth sciences department, and replaces John Corliss, who will continue working on ecological modelling at Biosphere 2. Under an agreement with Columbia, Biosphere 2 will pay an undisclosed sum for its assistance in setting up its new programme.
John Mutter, the interim director of Lamont-Doherty, says that what he describes as an "extraordinary facility" has in effect been released from its previous mission to become a serious scientific facility. "That presents a great opportunity for our scientists," he says.

Asked if Biosphere 2's track record would make it hard to attract support for research, Mutter says that "the only thing we can do is put that behind us. We were not involved in previous missions."

The seven-strong "crew" currently manning Biosphere 2 will emerge earlier than planned next month, cutting a link with the emphasis on human "survival" which critics had attacked as a gimmick, and opening the way for a more conventional programme of scientific experiments at the \$150-million facility (see Nature 368, 88; 1994).

Bass sacked the more holistically minded members of Biosphere 2's management earlier this year, and has been soliciting advice from outside scientists on how best to exploit the project's considerable scientific potential (see Nature 368, 576; 1994).

Biosphere 2 and Columbia hope to build a scientific programme that will attract substantial funding from outside sources such as the National Science Foundation. Given the physical attributes of the facility, and the Clinton administration's keenness to support environmental research, that should not prove too difficult.

Colin Macilwain 